University of California, Hastings College of the Law UC Hastings Scholarship Repository

Faculty Scholarship

1977

\title{
Barred from the Bar: Women and Legal Education in the United States 1870-1890
}

D. Kelly Weisberg

UC Hastings College of the Law, weisberg@uchastings.edu

Follow this and additional works at: http://repository.uchastings.edu/faculty_scholarship

Part of the Law and Gender Commons, and the Legal Education Commons

\section{Recommended Citation}

D. Kelly Weisberg, Barred from the Bar: Women and Legal Education in the United States 1870-1890, 28 J. Legal Educ. 485 (1977). Available at: http://repository.uchastings.edu/faculty_scholarship/782

This Article is brought to you for free and open access by UC Hastings Scholarship Repository. It has been accepted for inclusion in Faculty Scholarship by an authorized administrator of UC Hastings Scholarship Repository. For more information, please contact marcusc@uchastings.edu. 


\title{
Faculty Publications \\ UC Hastings College of the Law Library
}

\author{
Author: D. Kelly Weisberg \\ Source: Journal of Legal Education \\ Citation: 28 J. Legal Educ. 485 (1977). \\ Title: $\quad$ Barred from the Bar: Women and Legal Education in the United States \\ 1870-1890
}

Originally published in JOURNAL OF LEGAL EDUCATION. This article is reprinted with permission from JOURNAL OF LEGAL EDUCATION and Association of American Law Schools. See NOTE. 


\title{
BARRED FROM THE BAR: WOMEN AND LEGAL EDUCATION IN THE UNITED STATES 1870-1890*
}

\author{
D. KELLY WEISBERG**
}

One of the paramount concerns of any skilled profession is the regulation of access to the profession. As Chroust has pointed out, in colonial America any person desiring to be admitted to the legal profession had four major avenues of entry.

" $H$ e might, by his own efforts and through self-directed reading and study, acquire whatever scraps of legal information were available in books, statutes, or reports; he could work in the clerk's office of some court of record; he could serve as an apprentice or clerk in the law library of a reputable lawyer, preferably one with a law library; or he could enter one of the four Inns of Court in London and receive there the 'call to the bar.' "' 1

Chroust's use of the masculine pronoun above is not entirely without significance. "Any" person in colonial America did have four avenues of legal education open to him, provided that that person was male. The first hundred years of American legal education were characterized by a glaring absence of woman lawyers. This paper shall deal historically with women's entry into the legal profession after the Civil War in terms of their admission to law schools and to the bar.

The struggle for women to gain entrance to the legal profession began in the late 1860's with Ada Kepley the first woman to graduate from the Union College of Law (now Northwestern) in $1870^{2}$ and Arabella Mansfield the first woman to be admitted to the bar of any state (Iowa, 1869). However, the battle was by no means over; in reality it had just begun.

Scarcely two months after Arabella Mansfield was admitted to the Iowa bar, Myra Bradwell passed an examination for the Chicago bar, but the Illinois Supreme Court refused to grant her a license to practice law on the grounds of her sex. When the case was taken on a writ of error to the United

\footnotetext{
- Special acknowledgement is made of the assistance of Professor Egon Bittner, Brandeis University, and of Leonard Klein, Senior Reference Librarian, Harvard University Law Library, for facilitating the access to rare materials.

- Ph.D., Brandeis University.

1 Chroust, The Rise of the Legal Profession in America 173(1965).

'Several women attended some of the nation's law schools for brief periods prior to this date; however, Ada Kepley was the first woman both to attend and graduate from a school of law. Paradoxically, Mrs. Kepley was barred from the bar of Illinois upon first application by the adverse Bradwell decision cited infra.
} 
States Supreme Court, she was once again unsuccessful. ${ }^{3}$ In other landmark cases Lavinia Goodell was refused admission to the Wisconsin bar in 1875, ${ }^{4}$ Lelia Josephine Robinson was refused admission to the bar of Massachusetts in 1881, 5 and Belva Lockwood, although admitted to the District of Columbia bar and admitted to practice before the United States Supreme Court, was still refused admission to the Virginia bar in the 1890 's because of her sex. ${ }^{6}$

Even after the turn of the century when women were admitted to the bar of almost every state, ${ }^{7}$ the battle continued for women's admission to law school. Columbia University first admitted women law students in 1929, Harvard University in 1950 (although women had first applied to Harvard in the 1870's, ${ }^{8}$ the University of Notre Dame in 1969, and the last male bastion, Washington and Lee University in 1972.

In order to understand better the century of discrimination against women in terms of their access to the legal profession, it is helpful to examine the legal and social rationale utilized for the exclusion of women from the profession. Often the legal and social rationale cannot be separated, as will be seen in the court decisions of this period barring women. The legal rationale for denying women access to the profession may be seen to include the following:

\section{The Fight Over the Masculine Pronoun or Women as Non-Persons}

In most states admission to the bar was controlled by statutes. These statutes provided for the admission of "persons" or "citizens," or for specifically "male" persons or citizens. The language of the statutes was framed similar to the following:

"The Superior Court may admit and cause to be sworn as attorneys such persons as are qualified therefore agreeably to the rules established by the judges of said court, and no other person than an attorney so ad-

${ }^{3}$ Bradwell v. The State, 16 Wall. 130 (1872); 55 Ill. 535 (1869).

4 In Re Goddell, 39 Wis. 232 (1875).

'Ex parte Robinson, 131 Mass. 375 (1881).

'In re Lockwood, 154 U.S. 116 (1893). Virginia and Georgia still did not admit women to the bar in 1914. Cottle, "The Prejudice Against Women Lawyers: How Can It Be Overcome?" 21 Case and Comment 372 (1914).

7 By 1900, 34 states admitted women to the legal profession. Pettus, "The Legal Education of Women," 61 Alb. L.J. 330 (1900).

${ }^{8}$ When M. Fredrika Perry and Ellen Martin applied to the Harvard Law School in the 1870 's, the reason given for denying their applications for admission was that "it was not considered practicable to admit young men and young women to the Law Library at the same time, and it was not considered fair to admit to the Law School without giving the privileges of the Library." Martin, "Admission of Women to the Bar," 1 Chic. L.T. 83 (1886). The story of the admission of women to Columbia Law School may be found in Goebel, A History of the School of Law, Columbia University 290, 473 (1955). In 1924 the Columbia faculty unanimously resolved that "such a concession would be inexpedient and contrary to the best

${ }^{8}$ See p. 486. 
mitted shall plead at the bar of any court of this state, except in bis own cause." (emphasis mine)

or, the Wisconsin statute which specified:

"No person shall hereafter be admitted or licensed to practice ... except in the manner hereinafter provided . . . be shall be first licensed by order of. ..." 10 (emphasis mine)

The battle was waged over the masculine pronoun. That is, could the court (in the Goodell and Bradwell cases, for example) decide that words specifically importing masculine gender should extend to women and thereby admit women to the legal profession? The general rule of interpretation of the statutes was that "every word importing the masculine gender only may extend and be applied to females as well as males." "11 This was precisely the point on which Mrs. Mansfield was admitted to the Iowa bar. However, the judges in both Goodell and Bradwell maintained that the rule of interpretation applied "unless ... such construction would be inconsistent with the manifest intention of the legislature." 12 This brings us to another legal argument utilized to bar women from the legal profession.

\section{Surely, the Legislators Never Contemplated That!}

In establishing the rules by. which admission to the profession should be determined, the court was bound by two limitations, maintained Justice Bradley in the Bradwell decision. The first was to promote the proper administration of justice and the second, " . . that it should not admit any persons, or class of persons, not intended by the legislature to be admitted even though not expressly excluded by statute." 13

Supporters of this argument maintained that when the legislators first framed the statutes in the eighteenth century, they did not contemplate that

\footnotetext{
${ }^{8}$ cont'd.

interests of the Law School," Goebel, at 290. Yale Law School similarly has a shameful chapter in the history of women in legal education. Although Yale was technically one of the first law schools to admit a woman, the school later changed its policy. Alice Jordan entered Yale Law School in the fall of 1885 after studying at Michigan University and after being admitted to the Michigan bar. She received a degree from Yale shortly thereafter. However, as of 1890 the law school had reconsidered this decision and the catalogue specified: "It is to be understood that the courses of instruction above described are open to persons of the male sex only, except where both sexes are specifically included." Dean Wayland of the Law School wrote in private correspondence, "the marked paragraph on page 25 is intended to prevent a repetition of the Jordan incident." Robinson, "Women Lawyers in the United States," 2 Green Bag 13 (1890).

9 Quoted in "Women May be Admitted as Áttorney," Annotated Case, In re Hall, 21 Am. L. Reg. 728 (1882).

${ }^{10}$ Quoted in In re Goodell, 39 Wis. 233 (1875).

${ }^{11}$ Ibid.

12 Ibid. at 241.

${ }^{13}$ Bradwell v. The State, 16 Wall. 130 (1872).
} 
women would ever be admitted to the bar. Hence, in its original enactment, the application of the statute to women was not in the minds of the legislators. This interpretation naturally led to the conclusion that the court lacked the statutory authority to admit women to the legal profession. This was the interpretation utilized in both the Bradwell and Goodell decisions and by Justice Pardee in his dissent in In re Hall. ${ }^{14}$

In holding to this strict interpretation of legislative intent, the courts seemed influenced by an overriding concern with the social consequences of straying from the interpretation. In both the Goodell and Bradivell decisions (maintaining this lack of legislative intent) one finds the apocalyptic adumbration of the social consequences entailed by permitting women to enter the legal profession-namely, a sweeping revolution of the social order. As Justice Ryan maintained in Goodell:

"If we should follow that authority in ignoring the distinction of sex, we do not perceive why it should not emasculate the constitution itself and include females in the constitutional right of male suffrage and male qualification. Such a rule would be one of judicial revolution, not of judicial construction .... . We cannot stultify the court by holding that the legislature intended to bring about, per ambages, a sweeping revolution of social order, by adopting a very innocent rule of statutory construction."'15

Similarly, in the Bradwell decision, Justice Lawrence when delivering the majority opinion stated the consequence, fearful beyond imagination, that :

"This step, if taken by us, would mean that in the opinion of this tribunal every civil office in this state may be filled by women: that it is in harmony with the spirit of our Constitution and laws that women should be made governors, judges and sheriffs. This we are not pre pared to hold....'"16

\section{You Have Not, Ergo You Cannot-Common Lau' Disability}

Another common rationale utilized to bar women from the legal profession was the argument that the impediments growing out of women's legal status at the common law prevented them from gaining access to the profes sion. The fact that women had never been admitted to the bar had cstab lished a common law disability. And, supporters of this argument maintained, inasmuch as women were not known as attorneys at common law, this was sufficient reason for the court to refuse to admit them. It was argued, too, that women had other disabilities at common law which would interfere with their practice of the legal profession, such as their not being

\footnotetext{
${ }^{14}$ Quoted in "Women May Be Admitted as Attorney," supra note 9, at 735.

is In re Goodell, 39 Wis. 242, 243 (1875).

${ }^{16}$ In re Bradwell, 55 Ill 535 (1869).
} 
able to hold office at this time. This presented a problem because an attorney was an officer of the court. However, the most serious common law disability which would interfere with women practicing law, or so women's opponents maintained, concerned married women's inability to contract.

\section{If You're Married, You Can't be a Lawyer}

This legal rationale was based on the fact that married women at this time were disqualified from entering into contracts with third persons without their husband's consent. In both the Bradwell and Lockwood decisions, it was held that because of this disability at common law, married women could not be permitted to gain admission to the bar. ${ }^{17}$

However, in some decisions which admitted women to the bar, it was held that married women's inability to contract was not an insurmountable obstacle. In the Kilgore decision in Pennsylvania (admitting Mrs. Kilgore), Justice Thayer held that the essential basis of the relationship between lawyer and client was not in contract.

" But what difference does it make if she cannot be sued as upon a contract. There are other adequate remedies for neglect of duty, infidelity, or misbehavior in office, which are provided by law and to which she would undoubtedly be amenable. ... These laws are an ample security for the client in dealing with an attorney, even if she be a married woman." 18

It can be seen that this objection was not really the primary obstacle in the minds of opposing judges. Upon the filing of Mrs. Bradwell's printed argument, the Illinois Supreme Court held that no female was eligible to practice in the state of Illinois-be she married or single.

In addition to legal arguments, opponents of women's entry into the legal profession also utilized social rationale for barring women. One such rationale included the argument that woman's mental and physical nature rendered her unfit for legal practice.

\section{Inferior in Mind and Body}

Onc objection to women entering the legal profession was that women did not possess a "legal mind." Women's minds were thought to be more emotional than rational and logical-the requisite qualities of the legal mind. Moreover it was argued, women simply did not have the natural aptitude to perform the duties required by the profession. Or, as one woman said:

\footnotetext{
${ }^{17}$ Kanowitz points out that vestiges of this common law disability remain, as in United States v. Yazell, 382 U.S. 341 (1966). Kanowitz, Sex Roles and Society: Cases and Materials 199 (1973).

${ }^{18}$ Quoted in "Women as Advocates," 18 Am. L. Rev. 479 (1884).
} 
"We are also told that the successful lawyer must have a logical mind, and since the mind of woman is sadly lacking in this respect, her unfit ness for the legal profession is apparent." 19

Not only did women apparently lack the necessary mental qualities for the practice of law, but also they were thought to lack the physical staminil the profession required. The opposing forces maintained that women did not have the physical strength to follow "so arduous a calling as the law." 20 Women, it would seem, were possessed of an exceedingly delicate constitution which could not withstand the long hours of study and the conflicts of the courtroom. As Justice Ryan maintained in Goodell:

"There are many employments in life not unfit for the female char acter. The profession of law is surely not one of these. The peculiar qualities of womanhood, its gentle graces, its quick sensibility, its ten der susceptibility, its purity, its delicacy, its emotional impulses, its subordination of hard reason to sympathetic feeling, are surcly not qualifications for forensic strife. Nature has tempered woman as little for the juridical conflicts of the court room as for the physical conflicts of the battle field." 21

Nowhere are these stereotypes of woman's mental and physical nature as clearly brought into relief as in the whimsical story published in 1886 by Charles C. Moore (author of Moore on Facts) about the first woman lawyer who came to Litchfield Connecticut. ${ }^{22}$ The presence of these stereotypes in the story is all the more significant because the author seems in favor of (more precisely, enamoured with) the idea of woman lawyers.

As Miss Mary Padelford steps off the Claremont stage, Lawyer Walter Perry remarks, "'and if she possesses enough physical strength I wouldn't be surprised if she makes a success." She chooses Claremont (i.e. Litchfield) because it is 1100 feet above sea-level and "her health has never been exceedingly rugged." When Miss Padelford loses her first case in court, she (what else?) bursts into tears in the courtroom. Later, the constant study out of court "was sufficient of itself to tax her constitution to the utmost and long trials in court brought a mental and physical exhaustion her ambitious nature was hardly able to resist." After another courtroom incident she faints and falls from her chair. When the physician arrives, he diagnoses her condition as "brain fever." In a fitting finale, Lawyer Walter Perry and Miss Mary Padelford are married and enter into partnership. One might surmise that thereafter Mrs. Perry's health improved because of the physical and mental assistance of a male law partner. ${ }^{23}$

${ }^{19}$ Cottle, supra note 6 , at 371 .

${ }^{20}$ Ibid.

${ }^{21}$ In re Goodell, 39 Wis 245 (1875).

${ }^{22}$ It may be hypothesized, although it is nowhere stated, that the occasion which prompted this story was the successful application of Miss Mary Hall to the Connecticut bar in 1882 .

${ }^{23}$ Moore, "The Woman Lawyer," 26 Green Bag 525 (1914). This story first appeared in the Hartford Daily Times, May 17, 1886. 
The belief that women's physical disabilities rendered them unfit for law practice even took the form of maintaining that women's "peculiar physiological condition" (menstruation) would inhibit their practice of law. In answer to this objection, one author remarked: "Do the thousands of women who practice medicine, leave their patients to die when they are suffering from catamenial disturbances?" 24 Interestingly, it was not only men who protested that women's physiological condition would interfere with their practice of law. One woman opponent protested:

"How would a lawyeress be able to consult with her clients, when she was attacked by the nausea of the first few months of pregnancy? And afterward what a figure she would make in court, when, the months of her interesting situation being advanced, her curved lines become crushed with an anterior round line? And if the pains should come upon her in the heat of argument! That would be fine indeed! Would she invite her colleagues to serve her as midwives? And in childbirth, farewell to business! Poor clients! I assure you that I laugh to myself thinking of the ridiculous figure that a woman lawyer would make." 25

It was suggested on the death of one of the first woman lawyers, Lavinia Goodell, that perhaps the "hard usage and severe mental application incidental to a legal professional career' 26 had contributed to her early demise. In answer to this, supporters of women entering the legal profession maintained:

"Miss Goodell was forty-one years of age. Henry Armitt Brown, the noted lawyer of Philadelphia, died recently at thirty-two. We would like to suggest the query whether men are able to endure the hard usage. ...',27

\section{Justice Would Suffer}

Another argument proffered against women entering the legal profession concerned the fear that the interests of justice would suffer. The female sex, opponents maintained, was reputedly garrulous and wanting in discretion. ${ }^{28}$ Consequently, the interests of clients could not be entrusted to women's hands. This latter opinion is clearly expressed in a rather misogynic British law journal article of this period, "Prudes for Proctors":

"The fact that women are admitted to practise in the United States is sufficient to prevent the matter being passed off as a joke; but it must be remembered that, in the States, the principle that the client must be protected from the solicitor by the Courts, has almost entirely given

\footnotetext{
34 Frank, "The Woman Lawyer," 3 Chic. L.T. 411 (1899).

${ }^{23}$ Quoted in Throop, "Woman and the Legal Profession," 30 Alb. L.J. 466 (1884).

${ }^{26}$ Robinson, supra note 8, at 24.

${ }^{27}$ Ibid.

${ }^{28}$ Frank, supra note 24 , at 401 .
} 
place to the principle that the client can very well look after himself. In England the question has to be considered, whether the interests of clients can safely be entrusted to a woman's hands." 29

This concern äbout the interests of justice also took the form that the introduction of women into the field of advocacy would check the fighting instincts of lawyers. Moreover, it was thought that judgment would no longer be impartial if women lawyers were present in the courtroom. This belief was expressed as:

"There are some lawyers who go so far as to say that given a woman plaintiff and a woman attorney and the defense might just as well lie down if the case be before a jury." ' 30

Strains of this belief can be seen in the following anecdote. A woman lawyer asked her client why he came to her for legal assistance. The client, who had been tried and convicted of a crime and awarded a new trial by an appellate court, replied: “Well, ma'am, I reckon I've had justice. What I need now is mercy, and I figger them jurors will feel mightly sorry for me if all I have is a woman to defend me." ${ }_{31}$

\section{Mothers as Lawyers?-Role Conflicts}

However, the primary social rationale utilized to bar women from the legal profession centered on woman's traditional role in the family. The professional role of the lawyer was seen to be in direct conflict with the traditional roles of woman as wife and mother. In both the Bradwell and Goodell decisions, the judges delivered a lengthy discourse on woman's "sphere." The proper sphere for woman, they maintained, citing by way of authority the law of nature and the law of the Creator, was in the home. The decisions are worth quoting at length. As Justice Bradley stated in Bradwell:

"... the civil law, as well as nature itself, has always recognized a wide difference in the respective spheres and destinies of man and woman. Man is, or should be, woman's protector and defender. The natural and proper timidity and delicacy which belongs to the female sex evidently unfits it for many of the occupations of civil life. The constitution of the family organization, which is found in the divine ordinance, as well as in the nature of things indicates the domestic sphere as that which properly belongs to the domain and functions of womanhood ... The paramount destiny and mission of woman are to fulfill the noble and benign offices of wife and mother. This is the law of the Creator...." 32

\footnotetext{
29 "'Prudes for Proctors," 14 L.J. 746 (1879).

30 "A Woman Lawyer's Chances, 21 Case and Comment 380 (1914).

${ }^{31}$ Quoted in Drew, "Women and the Law," 47 W.L.J. 20 (1961).

${ }^{32}$ Bradwell v. The State, 16 Wall. 141 (1872).
} 
Similarly, Justice Ryan in Goodell maintained:

"The law of nature destines and qualifies the female sex for the bearing and nurture of the children of our race and for the custody of the homes of the world and their maintenance in love and honor. And all life-long callings of women, inconsistent with these radical and sacred duties of their sex, as is the profession of the law, are departures from the order of nature; and when voluntary, treason against it. ...",33

Woman's traditional role conflicted with the professional role of lawyer in terms of the divergent sets of priorities of the role sets. The socially approved role for woman as wife and mother had duties associated with it which were expected to be woman's first and primary obligation, superceding any other claim. For the lawyer, obviously, his occupation was intended to be his first priority. Or, as Justice Ryan had asserted in Goodell: "The profession enteres largely into the well being of society; and to be honorably filled and safely to society, exacts the devotion of life." ${ }^{34}$ For woman, quite clearly, only her husband and children were supposed to exact the devotion of her life.

The requisite personality attributes of the lawyer, moreover, were seen as incompatible with those necessary for the role of wife and mother. The lawyer was supposed to be aggressive-a skilled combatant in the juridical conflicts of the courtroom. Woman was seen as nurturant, gentle, tender. In short, she possessed personality attributes required for the fulfillment of the role of wife and mother. It was readily apparent that the two role configurations have mutually exclusive sets of attributes.

But what of the unmarried woman? If opponents were concerned with married women straying from their duties, should not the unmarried woman, then, be able to practice law? For the single woman who was not engaged in fulfilling the role of "her destiny," the law was still not to be considered as a possible occupation. The court in Goodell had this to say:

"The cruel chances of life sometimes baffle both sexes, and may leave women free from the peculiar duties of their sex. These may need employment. . . But it is public policy to provide for the sex, not for its superfluous members; and not to tempt women from the proper duties of their sex by opening to them duties peculiar to ours. There are many employments in life not unfit for female character. The profession of law is surely not one of these." 35

The single woman, thus, was free to enter some other occupation to provide for herself. The legal profession, women's opponents stoutly maintained, should remain forever barred both to her and to her married sisters.

${ }^{33}$ In re Goodell, 39 Wis. 245 (1875).

${ }^{34}$ Ibis. at 244, 245.

35 Ibid. 


\section{The First Women Lawyers}

The next issue which shall be dealt with here concerns the nation's first women lawyers. Recent articles on women and the law tend to celebrate in passing the nation's first woman to graduate from law school, or the first woman to practice in the United States Supreme Court, or the first woman to be admitted to the bar of particular states. However, in their overriding concern with the position of women lawyers today, authors have neglected to take the historical question one step further. Who were the nation's first women lawyers? What can be discovered about them and about their chapter in the history of American legal education? (Data for this section was based on two "who's who"' type articles on women lawyers published in 1886 and 1890 , in addition to several obituaries of the nation's first women lawyers). ${ }^{36}$

In 1870 approximately four women were attending the nation's law schools (although not all four would be permitted to graduate). The same year witnessed a total student population of 1,611 in thirty-one law schools. ${ }^{37}$ (However, the total number of law students was undoubtedly somewhat greater because it was common in this period to pass the bar through private reading and office apprenticeships without ever having attended a law school). By 1890 the number of women lawyers and law students in the United States had grown to approximately 135. In that same time period, the total law student population in the United States had risen to approximately 7,000 .

What can be determined about these first women lawyers? After 1870 when law schools slowly began admitting and graduating women (Union College 1870; Michigan 1871; Washington University, St. Louis, 1871; Howard University 1872; Iowa State 1873; National University, Washington, 1873), the majority of these women attended law school in preparation for the bar, occasionally after having studied for a year or two in a law office. Before that time, the handful of women who were admitted to the bar (or more accurately, who sought admission to the bar), such as Mrs. Belle Mansfield, Mrs. Ada Kepley, Mrs. J. Ellen Foster, Miss Alta Hulette and Mrs. Myra Bradwell, gained their instruction either at home (Mrs. Foster said she read Blackstone while rocking her babies) ${ }^{38}$ or in law offices. An interesting fact now comes to light: many of the first women to gain entrance to the legal profession were married women for whom the opportunities of law study and later, law practice, were availed to them by their lawyer-husbands. In 1890 approximately one-third of the total number of women law-

\footnotetext{
${ }^{36}$ Martin, supra note 8, at 76. Robinson, supra note 8. "Mary A. Ahrens," 21 Case and Comment 430 (1914). "Death of Miss Lemma Barkeloo," 2 Chic. L.N. 409 (1870). "Lelia

Robinson Sawtelle Dead," 24 Chic. L.N. 421 (1891).

${ }^{37}$ Friedman, A History of American Law 526, 527 (1973).

${ }^{38}$ Robinson, supra note 8 , at 21 .
} 
yers were married women and more than half this number were married to lawyers.

Many of these lawyer-husbands helped their wives in their struggle to be admitted to the bar. Many of the first women lawyers received instruction in their husband's law offices; and, some lawyer-husbands, such as P.A.L. Smith, worked to get legislation passed which would open the profession to women. As Mr. Smith wrote refuting the argument that admitting women to the profession would interfere with women's domestic affairs:

"'This is all bosh-for in the first place she may not have any domestic affairs to look after; and in the second place, she herself is the best judge as to whether it pays her better or suits her better to look after other business and pay some one to keep an eye on domestic affairs. One or two little domestic affairs are not expected to occupy all of a smart woman's attention, and in the meantime why shouldn't she be allowed to practice law if she wants to. My wife has studied hard, prepared herself for the bar, and is fully competent to stand the legal exam required of men and I see no reason convincing to me why she should not practice. She has studied at my request and anything I can do to secure her admission to the bar will be done." 39

After admission to the bar many of these women were further facilitated in their entrance to the legal profession by going into practice with their lawyer-husbands. In fact, Robinson reports that in 1890 there were twenty husband-wife law partnerships in the United States. ${ }^{40}$

It is likely, too, that single women were aided by influential male lawyer relatives. Many single women who sought admission to the bar came from families with notable members in the legal profession. One woman's father (the first woman to be admitted to the bar in Utah in 1871) was Attorney General of the Utah Territory. Another woman who graduated from the University of Michigan in 1888 had a father who was a circuit judge in the Hawaiian Islands. And, of Frederika Perry, it was said "she belonged to the Strong family which has furnished a great deal of the legal talent in the United States." ${ }^{41}$ Other women's fathers were famous judges-Bessie Bradwell's father, for one, and Mary McHenry's father who was renowned in both California and Louisiana. Other single women had fathers who were practicing lawyers and often, after these women were admitted to the bar, they entered into partnerships with their family members.

\footnotetext{
${ }^{39} \mathrm{Ibid}$. at 181. (Miss Robinson commented on Mr. Smith's remarks: "Who would not be willing to stand up in a horse car when this new nineteenth century gallantry is given us in exchange for the superficial kind.') It is interesting to note that some lawyers' wives who studied law did so either at the request of their husbandss (Annie Smith, Corinne Douglass), or as in the case of Myra Bradwell, in order to assist their husbands. See DeCrow, Sexist Justice 30 (1974).

${ }^{10}$ Quoted in Frank, supra note 24, at 409, from personal correspondence.

11 Martin, supra note 8 , at 82 .
} 
Surprisingly, in such families one finds family combinations of women seeking entrance to the bar-mothers and daughters or sister pairs. Myra Bradwell and her daughter Bessie both sought admission and Kate Pier and her mother graduated together from the University of Wisconsin in 1887. Among the sister pairs are included the Spaulding sisters from the University of Wisconsin and the Cronise sisters who were admitted together to the state courts in Ohio in 1873. The Pier mother and daughter eventually joined Mr. Pier in a partnership and the Cronise sisters also formed a partnership until one of them married and left the profession. It may be surmised that originating from families with such concentrations of legal talent eased the way into the legal profession for many of these women.

Of the women lawyers who entered into active practice, what was the nature of their practice? Many who "actively" entered the profession, it would appear, ended up doing the office work and occupying a back seat to male lawyers. In the case of Mrs. Mary Haddock (in partnership with her husband), she "devoted herself principally to office work and briefing cases," and for Mrs. LeValley "her share of the work has been principally in the office." Tabitha Holton, in partnership with one of several lawyerbrothers, "devoted herself chiefly to office work," and Miss Jessie Wright after her marriage "assisted her husband in some of his work," similar to Mrs. Frank Helmer (Bessie Bradwell) who from time to time "aids her (lawyer) husband in his business." 42

Staying in the office was not only the fate of women lawyers in partnership with husbands or brothers. It seems this was also the fate of other early women lawyers as well. Of Miss Emma Gillet it was said, "her work has been principally in the office line-the drawing of papers, taking testimony in equity causes and probate business, together with a large amount of notarial and some financial work." Similarly, Mrs. Eliza Chambers gave her attention to such matters as equity, pensions and land claims.

The preponderance of "office work" done by women lawyers may well have been understandable in view of public prejudice. Many women lawyers may have been anxious to escape criticism and censure from the public and from other members of the legal profession and for these reasons chose to remain inconspicuous. Yet surprisingly enough, one finds a handful of these first women lawyers fearlessly engaging in criminal work. Mrs. Addie Billins in partnership with her husband was involved in several criminal cases and Mrs. Martha Strickland was active in criminal prosecutions as the assistant prosecuting attorney in Detroit. Mrs. Laura De Force Gordon had a substantial criminal practice (and represented a client in People v. Sproule, termed in 1900 " the most remarkable trial in California criminal jurisprudence"). Kate Kane wrote that in criminal law she had either prosecuted or defended every crime known to modern times except treason and piracy. And, Mrs.

\footnotetext{
${ }^{12}$ Robinson, supra note 8, at 10.
} 
Marilla Ricker's interest in the defense of criminals earned her the name of "prisoner's friend."

Later in the history of women in the legal profession, it appears that the profession was quite willing to allow women to take over this specialty, if one can go by the remarks of Clarence Darrow. In an address to a group of women lawyers in Chicago, Darrow stated:

" And there is another field [after divorce] you can have solely for your own. You won't make a living at it, but it's worth while and you'll have no competition. That is the free defense of criminals." 43

\section{Where to Practice?}

Where did these first women lawyers practice in light of public prejudice? For married women with lawyer-husbands, as we have already seen, many did not have to face this difficult decision because they entered into practice with their husbands (although occasionally they confronted another difficulty as in the states of Massachusetts and New York where married women were not able legally to form partnerships). However, for single women the answer to where to practice was oftentimes more problematic. In some instances these women were advised to open a practice in their home town and presumably thereby diminish public criticism. Often however, if they wished to practice at all, many women had little choice but to move to a state where it was permitted by law. The case of Mary Hall is illustrative of this. Before applying for admission in her home state of Connecticut, she seriously considered going to a state where women were already admitted to the bar "dreading the noise and criticism to which a pioneer in such a matter is always subject." 44 Miss Lemma Barkeloo furnishes another example. After being refused admission to law school in her native state of New York, she left her home and went to Missouri where she was admitted to Washington University. In her obituary was the following story by the Honorable Albert Todd:

"At the close of the last session of the law school, she called at my office to consult me about opening an office here. She said her parents lived in Brooklyn, New York. I advised her to open her office at home,

\footnotetext{
${ }^{43}$ Quoted in Drew, supra note 31, at 21. In an interesting cultural comparison it appears that French women lawyers were similarly 'bestowed' this specialty by the legal profession. As Lilly wrote: "The woman lawyer is everywhere in the criminal courts in Paris... The men lawyers voted this field of the law entirely to her, and most enthusiastically does she fill it. With my American commercialism, I could not help speculating as to whether or not the men would have so gallantly accorded this distinctive place in the law courts to the women had there been any money in this particular field." Lilly, "The French Women Lawyers," 21 Case and Comment 431 (1914).

14 Robinson, supra note 8, at 28.
} 
where she would have the support of her friends. She said she had though of that....",45

In the end, however, Miss Barkelon decided to stay in the "West,' ' because "the western people were generous and liberal in their sentiments and she would be better sustained here than in the East." "46

An interesting discovery that emerged from this research is that the West afforded better opportunities for women lawyers than the East. In fact, Robinson goes so far as to say that "It is undoubtedly owing to the Western spirit of liberality that women have ever been recognized at the bar in this country at all." 47 The first women lawyers were found predominantly in four states: Illinois, Iowa, Michigan and Wisconsin. (It is in these states where law schools first admitted women students).

Two husband and wife teams (Alice Jordan Blake and her husband and Sara Kilgore Wertman and her husband) moved as far west as Washington, although it can only be surmised that the diminution of prejudice against women lawyers was a contributory reason for their move. The most noteworthy case of the western mobility of the woman lawyer was Lelia Robinson Sawtelle. After seeking admission to the Massachusetts bar, she left for the Washington Territory where she "established herself in practice with the expectation of remaining permanently." 48 The opportunities there which were unavailable in the East can be seen:

"There she gained a valuable experience in court work (which she scarcely attempted in Boston) in trying and arguing cases before mixed juries of men and women in a new and progressive territory." 49

(It is important to note, of course, that the opportunities in the West not only attracted women lawyers, but attracted male lawyers as well. They also flocked to the West as it opened up). ${ }^{50}$

Lest it be thought that all the women who gained entrance to the legal profession in this epoch eventually practiced, suffice it to say that approximately one-fifth of the total number of women lawyers never practiced at all. Some women studied without the intention of practicing. Others married and became entrapped by domestic duties. In some instances, as with Rebecca May and Mary McHenry, women's husbands refused to let them enter active practice after their marriage.

Some women drifted into other fields because, it may be surmised, there they encountered less prejudice. Of these women some went into education. Belle Mansfield (the first woman to be admitted to the bar of any state) took a

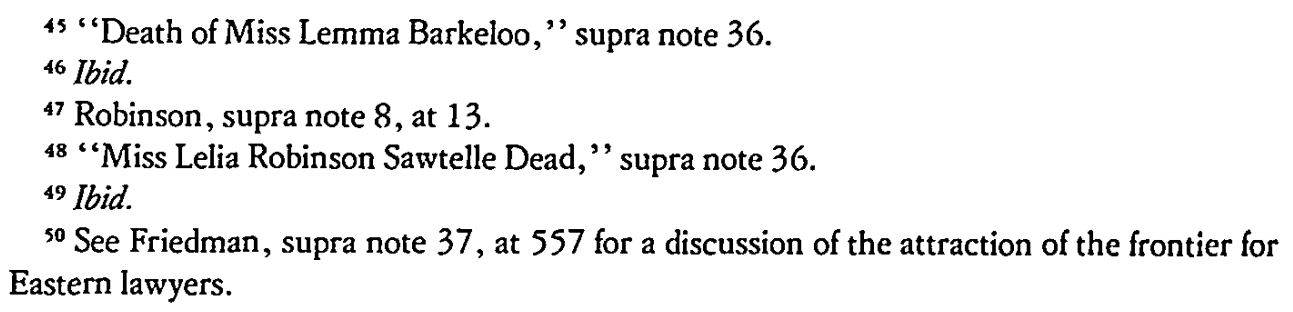


chair in history at De Pauw University. Catherine Waugh (before becoming the famed suffragist) was a professor of commercial law. Some women entered the literary field. One woman became a legal editor for West Publishing Company in 1886. Another woman became an author of legal texts (Marietta Shay, author of Students' Guide to Common Law Pleading). Bessie Bradwell Helmer compiled the last ten volumes of Bradwell's Appellate Court Reports, while her famous mother (Bradwell v. Illinois) became editor of "The Chicago Legal News." Catherine V. Waite became the editor of "The Chicago Legal Times."

It appears that many of these first women lawyers were well-to-do women, as can be deduced both from their mobility and from the concentration of legal talent in their families. Also, many of these women were extremely vocal. In addition to those women who expressed their opinions by virtue of their positions on periodicals, many women lawyers were involved in the social movement of temperance or in politics, as was Belva Lockwood, the first woman to run for President of the United States. (Mrs. Lockwood quite rightfully argued that although women could not vote, there was no reason they could not be voted for! $)^{\text {s1 }}$

\section{Historical Context}

The century of struggle for women to gain admission to the legal profession can only be understood by placing it in its historical context-with its roots in the struggle for women's rights in the United States. Only then can the question be answered as to why this struggle of women lawyers took place at this particular time in American history.

At the beginning of the nineteenth century women were not given access to higher education because of their sex. While they were permitted to attend elementary schools since the early days of American history, their admission into secondary schools and universities took much longer. It was considered a waste of money to educate women-not only because women's minds were thought to be inferior to men's, but also because women's function was to bear and raise children and an education was deemed superfluous for this task.

Before 1814, education for women was limited to the "well-to-do"s2 and consisted of such pursuits as embroidery, painting, French, singing and playing the harpsichord. However, one event significantly altered this-the discovery of the first power-driven loom in Waltham Massachusetts which

\footnotetext{
31 For a discussion of this presidential race (which Mrs. Lockwood claimed "did more to awaken American women to their political powers than anything that happened in the nineteenth century") see Abernathy, "Belva A. Lockwood: A First Lady," 33 Phi Delta Delta 8 (1954).

52 Flexner, Century of Struggle: The Women's Rights Movement in the United States 23
} (1973). 
launched the first large-scale industry in the United States. During the period of industrial development and westward expansion following the Louisiana Purchase, women not only entered the textile mills in vast numbers but also were in increasing demand as teachers for the rapidly growing population. Consequently, "the need to equip them for the new duties being laid upon them was harder to deny." 53

The battle for broader opportunities and rights for women really revolved around the issue of education, maintains Atkins. ${ }^{54}$ Such early American feminists as Mary Wollstonecraft, Hannah Crocker, Emma Williard and Frances Wright all stressed the importance of education for women. The first publicly endowed institution for the education of women opened in 1821 and by the end of the 1830's seminaries and colleges for women were beginning to be established. Oberlin, in 1833, was the first institution of higher education to admit all students regardless of race or sex (although women here took a shortened literary course in accordance with the belief that their minds could not assimilate the same fare as men's and the belief that their education better prepared them for intelligent motherhood). ${ }^{5}$ In 1837 with the founding of Mt. Holyoke, the concept finally took hold that women needed an improved education for more than carrying out their housewifely duties. Later developments in the nineteenth century saw the opening of Vassar (1865), Smith and Wellesley (1875) and the Harvard Annex (Radcliffe) in 1879.

The struggle for co-education for women proceeded hand-in-hand with the struggle for such equal rights for women as custodial rights for their children, owning property, the right to work at a job and the right to control their own earnings. The roots of these various struggles (and of the fight for suffrage which often overshadows them) can be found in the anti-slavery movement: it was the slavery issue that provided the spark which ignited the feminist movement. Before the 1840's feminism was an unorganized social movement. However, after that period women began organizing in several major American cities to form anti-slavery societies. As Flexner describes:

"It was in the abolitionist movement that women first learned to organize, to hold public meetings, to conduct petition campaigns. As abolitionists they first won the right to speak in public and began to evolve a philosophy of their place in society and of their basic rights. For a quarter of a century the two movements, to free the slave and to liberate the woman, nourished and strengthened one another." 56

Thus, it was the abolitionist movement which first brought women out of

${ }^{53}$ Ibid. at 24.

54 Atkins, The Hidden History of the Female: The Early Feminist Movement in the United States 3 (n.d.).

55 Flexner, supra note 52 , at 30.

${ }^{56} \mathrm{Ibid}$. at 41 . 
the home and encouraged them to speak out for their rights-one of which was co-education. Once women gained ground in co-education in colleges and universities, it undoubtedly seemed the logical next step to continue the fight for co-education in law schools.

Interestingly, the fight for women's rights netted better results in the western United States than in the East. This also explains the reason why many women lawyers migrated westward. The Wyoming Territory was the first to grant full suffrage rights to women in 1869. And, in addition to giving women state control of their property and protecting them from discrimination as teachers, Wyoming also permitted the first women to sit on juries. ${ }^{57}$ The westtern state of Utah, then the Utah Territory, followed Wyoming in 1870 by granting women the vote. (However, the EdmundsTucker Act illegalizing plural marriage passed by Congress in 1887 also revoked women's suffrage in Utah and Utah women did not regain the vote until 1896). The realities of frontier life and the shortage of labor there resulted in women undertaking considerable responsibilities in daily activities. This gave little credence to the idea that women were inferior and should lead sheltered and protected lives.

\section{Suffragists?}

The obvious question which comes to mind is: how many of these first women lawyers were active in the women's rights movement in the late nineteenth century? One might hypothesize that the majority of the first women to gain entrance to the legal profession would have been staunch women rightists. Perhaps, even, many were early suffragists? Yet, an examination of the biographical materials on the first women lawyers and a cross-tabulation of several sources on the suffrage movement reveal that only a few of these women evidenced their support of women's rights by being ardent suffragists. The names of women lawyers in this period which have come to light in the suffrage movement include: Mary Ahrens, Emily Buckhout Baker, Phoebe Cousins, Clara Foltz, Belva Lockwood, Catherine Waugh McCulloch and Marilla Ricker, ${ }^{58}$

The number of suffragist-lawyers may have been somewhat greater based on the fact that several additional women lawyers are found in the temper-

\footnotetext{
57 Flexner, supra note 52, at 161, maintains that the jury issue in Wyoming caused a greater storm than the issue of suffrage. For a discussion of the first women jurors, see Robinson. "Women Jurors," 1 Chic. L.T. 22 (1886).

${ }^{58}$ Data veryifying the role of these women in the suffrage movement may be found for Mary Ahrens in her obituary, supra note 36; for Phoebe Cousins in Raye-Smith, "A Light that Failed," 2 W.L.J. 45 (1914); for Clara Foltz in Johnson, The Bar Association of San Francisco: The First Hundred Years (1973); for Belva Lockwood in Abernathy, supra note 51 ; for Catherine McCulloch in Kraditor, The Ideas of the Woman Suffrage Movement 229 (1965); and for Marilla Ricker in Flexner, supra note 52, at 165.
} 
ance movement in this era. It is known that many women's rights supporters came to the suffrage movement through temperance. ${ }^{59}$ Among the women lawyers whose names are found in the temperance movement were: Mrs. Ada Kepley, Mrs. J. Ellen Foster and Mrs. Ada Bittenbender. However, it can not be stated conclusively whether these particular women were women's rights supporters.

What of the links between the women's rights movement in the United States and the first women lawyers? The apex of American feminism occurred in the period 1890-1920. A survey of several volumes of the Women Lawyers' Journal after its inception in 1911 reveals that many women lawyers in this later period actively participated in the suffrage movement. In fact, in these later years, the link between the women's rights movement and women lawyers is very clear. In this period, the Women Lawyers' Journal carried frequent articles on suffragists, on the formation of suffrage clubs, on the progress of equal suffrage, and on women lawyers who were appointed to positions in suffrage associations. In addition, many members of the. Women's Lawyers Club (which published the Women Lawyers' Journal) were prominent suffragists. It was not uncommon to find in the Journal a comment such as the following:

"It is expected that the women lawyers of the country will respond to the call for marchers in the suffrage parade in Washington on March 3, the day previous to the inauguration of President Wilson." 60

However, of the women lawyers in the earlier period of 1870 to 1890 , it can more likely be assumed that the majority of these women were not radical feminists. A few of the first women lawyers may have been "quiet" feminists, such as Mrs. Anne Saveny who practiced for the benefit of women, or the Cronise sisters who took several women law students to train in their office. By and large, however, it appears that the overwhelming majority of these first women lawyers were individualists-individualists who were content to earn their law degrees and then to disappear from public life. Rarely do we find these first women lawyers speaking out publicly for women's issues, demanding the vote or greater rights for women or seeking legislation to further woman's cause. ${ }^{61}$

Rather, what appears to be the case is that these first women lawyers benefitted from the concurrent struggle of the women's rights movement for coeducation. As opportunities for higher education for women opened up, so naturally did opportunities in the nation's law schools. These first women

59 Firestone, The Dialectic of Sex: The Case for Feminist Revolution 488 (1970).

${ }^{60}$ See 2 W.L.J. 59 (1913).

61 Women such as Myra Bradwell seem to have been the exception rather than the rule among these first women lawyers. Mrs. Bradwell drafted and urged the Illinois state legislature to pass a law establishing married women's rights to their earnings and also won passage of laws guaranteeing to a widow a share in her husband's estate. See DeCrow, supra note 39, at 31 . 
lawyers were undoubtedly influenced by the feminist struggles of their day and benefited therefrom. However, the vast majority of these women failed to see woman's cause as a legitimate social issue and only viewed it insofar as it helped their cause in terms of gaining access to the legal profession.

\section{Parallels Today}

What parallels and similarities can be noted between the first women lawyers in the United States and women lawyers today? First, it appears that a high proportion of women in the legal profession today, similar to the women lawyers of $1870-1890$, tend to have lawyers in their family who are influential in their decision to study law. Barnes discovered in a study at the University of Virgina that the reason most often cited by women law students for studying law was that a member of their family was an attorney. ${ }^{62}$

It also appears that a large number of married women lawyers today are married to lawyers, as was also found among the nation's first woman lawyers. Glancy in a study of Harvard women law school graduates reports that of the married women in the sample $63 \%$ were married to lawyers. ${ }^{63}$ She noted: "the husbands of the women lawyers tended to be more enthusiastic or approving of their lawyer-wives' legal careers than the wives of the men in the sample." 64 The significance of this finding seems to lie in the influence of a lawyer-husband. Although it was not determined in these cases whether the women's interest in law preceded her marriage or whether her marriage to a lawyer fostered her interest in law, the support of lawyer-husbands seemed to be an important motivating factor to these women in their pursuit of law studies and a legal career. This finding of the importance of supportive husbands of professional women has also been reported in other studies - as with women doctors. Lopata has found:

"Whatever the girl's hopes may be, however, it is her husband, if she marries, who ultimately determines the possibility of continuing in her profession while being a wife and mother." 65

Bernard has noted from the sociological literature on the professional woman what she terms the "law of husband cooperation." She explains:

"... studies show that integrating a domesic and a professional role depends on the cooperation of one's husband. Without it, all else is impossible. The road is just too rough. And if there is opposition, the game is up. . " 66

In the nineteenth century whether the woman lawyer eventually practiced often depended on the support she received from her husband. If support was

62 Barnes, "Woman and Entrance to the Legal Profession," 23 J. Leg. Ed. 289 (1971).

${ }^{63}$ Glancy, "Women in Law: The Dependable Ones," Harv. L.S. Bull. 23 (1970).

${ }^{64} \mathrm{Ibid}$.

65 Lopata, "Marriage and Medicine," in Theodore, The Professional Woman 54 (1971).

${ }^{66}$ Bernard, The Future of Motherhood 162 (1974). 
given, the woman generally went into practice-often into practice with her husband. However, if support was not forthcoming, she was more likely to remain in the home after marriage, confined to domestic duties. It would be interesting if after 100 years the same were true today: whether the married woman lawyer successfully integrates a professional and domestic career may depend on the degree of support she receives from her husband.

Another similarity is that women lawyers today, similar to the first women lawyers, tend to see fewer clients than their male counterparts. While women lawyers practicing in the late 1890's tended to maintain low visibility by remaining in the office doing office work, this phenomenon of low visibility in terms of client relations seems to hold true even of women today. According to both White and Glancy, women lawyers today deal with fewer clients than do male lawyers. ${ }^{67}$ In addition, many women lawyers currently maintain low visibility by going into government-related work and by avoiding high visibility specialties such as criminal litigation. It is likely that by seeking low visibility, women lawyers hope to minimize discrimination and client prejudice toward them.

This characteristic of women lawyers is also true of the professional woman generally. It is a phenomenon Epstein has called "being unobtrusive." She has noted that women in the professions try to be unobtrusive and to avoid attention by accepting work which keeps them in invisible positions.

"This unobtrusiveness is a reflection of women's position within the informal structure of the profession. Women are sensitive to men's desire to be left to their own company ... By bowing to pressure to make themselves unobtrusive ... women are accepting common definitions about the inappropriateness of their presence in the field in which they have chosen to work. . . "' 68

Perhaps one reason for professional women and for women lawyers specifically to seek a low profile may lie in the conflicting behavioral expectations they face today, similar to those found in the nineteenth century. As Armstrong has noted: "A well-dressed, acquainted and endowed woman applicant arouses immediate suspicion although this is just what firms pray for in a man." 69 The qualities most admired in men-confidence, ambition, self-assurance, assertiveness, aggressiveness, competitiveness-are looked upon with disfavor in women because they conflict with the traditional image of the sex. Yet, paradoxically, these qualities historically have been and still are the qualities which are viewed as prerequisites for the successful lawyer.

67 White, "Women in the Law," 65 Mich. L. Rev. 1093 (1967); Glancy, supra note 63. ${ }^{68}$ Epstein, Woman's Place: Options and Limits in Professional Careers 192 (1970).

${ }^{69}$ Armstrong, "Women in the Law," Harv. L.S. Record, Dec. 6 and 13, 1951, at 2. 
It is important to note that women, historically, have not been the only target of discrimination by the legal profession. Similar exclusionary practices existed throughout the history of American legal education against Blacks, Jews and immigrants. Much of the discrimination against the latter two groups occurred in the period $1900-1922^{70}$ when hostility on the part of leading acadmicians and practicing lawyers was directed at night schools because of the ethnic composition of their student body.

It would appear that the period of the multiplication of law schools which occurred during the peak years of immigration from 1905 to 1914, as documented by Auerbach, bore a striking similarity to the period of Jacksonian democracy described by Stevens. ${ }^{71}$ Both periods were marked by pressures upon the legal profession from those who demanded a freely swinging door to the profession. During the Jacksonian period, the surge of feeling which exalted the common man held that all male citizens had the inherent right to practice law. Similarly for immigrants after the turn of the twentieth century, access to the legal profession became an index of American democracy. Both periods witnessed vigorous debates over the qualifications for admis, sion to the bar.

In the first two decades of this century, the plea among members of the legal profession for higher standards was actually thinly concealed anti-Semitism and xenophobia. As Auerbach writes:

"Cries of overcrowding swelled the chorus of complaints about commercialization and declining ethics. The culprits were the 'unlearned, unlettered and utterly untrained young lawyers with no esprit de corps and little regard for the traditions of the profession.' In translation this meant immigrants and Jews. ..."72

Anti-Semitism in the legal profession goes back even further in American legal history. George T. Strong in his diary in 1874 supported the idea of a test for admission to Columbia Law School by writing:

" . . . either a college diploma, or an examination including Latin. This will keep out the little scrubs (German Jews mostly) whom the School now promotes from the grocery-counters ... to be 'gentlemen of the Bar.', 73

As might be expected in the history of American legal education, we also find considerable discrimination against Black law students and lawyers. Such discrimination is especially pronounced in the South where until a

\footnotetext{
70 Auerbach, "Enmity and Amity: Law Teachers and Practitioners 1900-1922," 5 Perspectives in American History 551 (1971).

"Stevens, "Two Cheers for 1870: The American Law School," 5 Perspectives in American History 417 (1971).

72 Auerbach, supra note 70 , at 584 .

${ }^{73}$ Quoted in Friedman, supra note 37, at 553.
} 
decade ago, Mississippi had three Black lawyers to serve a Black population of 800,000 and seven years ago Alabama had 20 Black lawyers and Georgia had $34 .{ }^{74}$ Seven years ago there were only 22 first-year Black students at 17 predominantly white Southern law schools. Many Southern law schools until recently, "have been white law schools where blacks were simply not admitted." 75 Thus, it appears that women, historically, have shared the dubious honor of being targets of discrimination by the legal profession with such other minority groups as Jews, Blacks and immigrants.

\section{Discrimination Today}

What of discrimination and the position of women in the legal profession today? This question has received much attention recently. ${ }^{76}$ Women are applying to law schools in greater numbers than ever before. Since 1969 the overall number of applicants to law schools has tripled, while in the same period the number of female applicants has increased 14 times. $^{77}$

Women comprised $16 \%$ of all students entering law school in $1972 .{ }^{78}$ Although this figure constitutes a dramatic rise from previous years, the figure is strikingly low when one realizes that $51 \%$ of the population is female. As of 1975, only one law school, Northeastern University, had yet achieved population parity and it is doubtful if many others will swiftly follow this guideline.

The participation of women lawyers in the legal profession has risen slowly since 1910 . In that year women constituted $1.0 \%$ of the profession. A half century later, in 1960 , they constituted only $3.5 \% .{ }^{79}$ Moreover, the ratio of women lawyers to the total membership of the legal profession has actually declined from approximately 1 in 28 in 1950 to 1 in 40 by $1970 . .^{80}$

In terms of job placement, a 1972 Association of American Law Schools (AALS) questionnaire revealed that significant discrimination against women lawyers still exists. Forty percent of the respondent schools said that

\footnotetext{
74 Making the Legal System Work: How Black Students Become Lawyers in the South," 22 Carnegie Quarterly 3 (1974).

${ }^{75} \mathrm{Ibid}$.

${ }^{76}$ Some of the most comprehensive recent articles include: Barnes, "Women and Entrance to the Legal Profession," supra note 62; Bysiewicz, "Women Penetrating the Law," 9 Trial 27 (1973); Ginsburg, "Treatment of Women by the Law: Awakening Consciousness in the Law Schools," 5 Val. U. L. R. 480 (1971); Read and Petersen. Sex Discrimination in Law School Placement," 18 Wayne L. Rev. 639 (1972): White, "Women in the Law," supra note 66.

${ }^{77}$ Bysiewicz, supra note 76, at 27.

${ }^{78} \mathrm{Ibid}$.

79 Epstein, "Encountering the Male Establishment," in Theodore, supra note 65.

${ }^{80}$ Sassower, "Women in the Law: The Second Hundred Years," 57 A.B.A. J. 330 (1971).
} 
they had received complaints of discrimination from female students being interviewed by law firms. ${ }^{81}$ In addition, the AALS study revealed that women tend to be underrepresented on the faculties of law schools and tend to cluster at lower levels than their male counterparts.

Sassower reports that women lawyers have been losing ground in terms of holding positions of prestige within the profession: every woman who left the bench in New York State within the past twenty years was replaced by a man. She further notes that most top courts, federal and state, have yet to break through the sex barrier. ${ }^{82}$ In addition, she reports that women hold a very small number of positions in the major law firms. Of 2,700 lawyers employed by forty top law firms in six major cities, only 186 were women.

White has revealed that a significant income differential exists between male and female lawyers. ${ }^{83} \mathrm{He}$ reported that in the first year of practice, a $\$ 1,500$ income differential is apparent. Gradually however, men increased their income to the point where they were earning nearly double their female colleagues.

That discrimination still exists in the legal profession is scarcely a point in need of belaboring here. Women were absent in the first hundred years of legal education in America. In the second hundred years they made slow progress: one hundred years after Ada Kepley became the first woman to graduate from law school, the last male bastion of legal education finally permitted women to enter the first-year class. It can only be hoped that women will occupy a more prominent position in the legal profession in the century to come.

81 Bysiewicz, supra note 76, at 27.

${ }^{82}$ Sassower, supra note 79, at 330 .

${ }^{83}$ White, supra note 76 , at 1069. 